Open Science for Fisheries, 1(1): 1-5, I July 2020

\title{
Pemanfaatan Telur Landak Laut Diadema setosum di Pulau Taliabu, Maluku Utara, Indonesia
}

\author{
La Nane* \\ *Jurusan Manajemen Sumber Daya Perairan, Fakultas Perikanan dan IImu Kelautan, Universitas Negeri \\ Gorontalo. Email: Ianane@ung.ac.id
}

\begin{abstract}
Landak laut Diadema setosum merupakan salah satu biota laut ekonomis dan dikonsumsi secara luas di Pulau Taliabu, Kabupaten Taliabu, Maluku Utara. Telur landak laut Diadema setosum ini telah secara luas dikonsumsi terutama secara segar (mentah) maupun olahan berupa kukure. Pemanfaatan telur landak laut $D$. setosum di Pulau Taliabu masih dilakukan secara rekreasi dan tradisional dengan menggunakan alat tangkap seadanya seperti parang dan karinda. Penggunaan alat tangkap ini masih digunakan sampai sekarang, karena dianggap lebih efektif. Meskipun penangkapan telur landak laut $D$. setosum sudah dilakukan sejak lama. Namun, sumber daya landak laut $D$. setosum masih melimpah dan tidak mengalami overfishing.
\end{abstract}

Keywords: Landak Laut; Diadema setosum; Pulau Talaibu; Indonesia

(ㅇ) $(\Theta \odot)$

How to cite: Nane, L. (2020,). Pemanfaatan Telur Landak Laut Diadema setosum di Pulau Taliabu, Maluku Utara, Indonesia. Open Science for Fisheries, 1(1), 1-5. https://doi.org/10.31219/osf.io/kmtuv

\section{Introduction}

Landak Laut Diadema setosum (Fig. 1) merupakan salah sumber daya perikanan penting karena bernilai ekonomis dan telah diperjualbelikan secara global. Telur landak laut D. setosum ini bahkan telah banyak dikonsumsi oleh konsumen lokal di Indonesia terutama bagi masyrakat pesisir di P. Taliabu, Kabupaten Taliabu, Maluku Utara.

Landak laut Diadema setosum ini umumnya hidup secara berkelompok atau bergerombol membentuk kelompok-kelompok baik dalam jumlah yang kecil maupun besar. Ciri khusus biota ini adalah warna kulitnya yang hitam pekat dan duri-durinya yang panjang. Karena itu ia dikenal dengan nama umum landak laut berduri panjang (long-spined sea urchin). Duri panjang pada landak laut tidaklah beracun. Karena duri panjang tersebut hanyalah kaki yang digunakan sebagai kaki untuk bergerak atau mencari makanan.

Selain duri sebagai kaki untuk bergerak, bulu babi $D$. setosum ini juga memiliki duri yang beracun. Fungsinya adalah sebagai alat pertahanan tubuhnya dari pemangsa. Ukurannya lebih pendek dari kaki jalan, lebih halus menyerupai belaian rambut dan terletak di selasela kaki jalan. Karena itu, kita dapat memegang 
bulu babi ini tanpa menggunakan alat pelindung tangan dengan catatan tidak mematahkan kaki jalannya. Sehingga aman dan tidak tertusuk oleh duri bisanya Ketika disentuh atau dipegang.

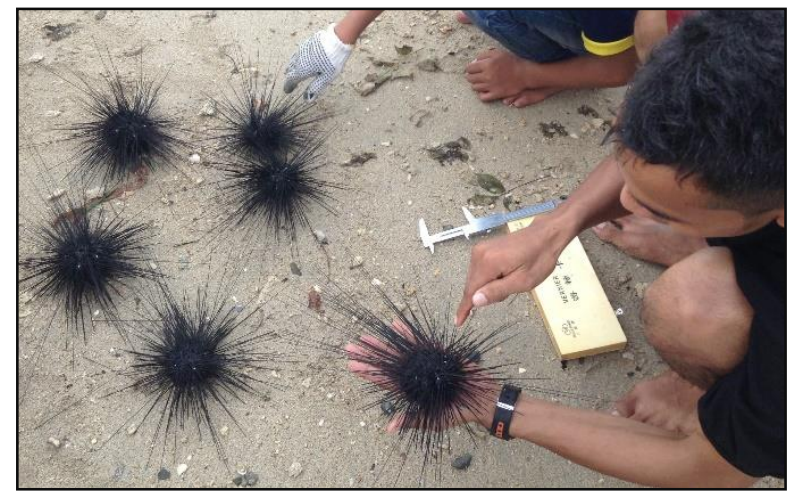

Fig. 1. Landak Laut Diademe setosum

Warna bulu babi D. setosum berwarna hitam pekat. Karena itu mudah untuk ditemui bila dicari baik pada kondisi air pasang maupun posisi surut karena warnanya yang hitam dan hidupnya yang mengelompok di alam. Sungguhpun pada kondisi tertentu, ada juga landak laut $D$. setosum yang ditemukan menyendiri. Akan tetapi sifat alami atau natural Landak laut $D$. setosum ini umumnya mengelompok dan hidup pada daerah pasir atau pasir berbatu di antara sela-sela padang lamun maupun terumbu karang (Nane et al., 2020).

Dewasa ini, masyarakat pesisir di Kepulauan Taliabu memanfaatkan telur landak laut $D$. setosum bukan saja untuk tujuan konsumsi, tetapi juga untuk tujuan ekonomi. Namun, kegiatan penangkapan landak laut $D$. setosum di P. Taliabu belum menjadi target atau mata pencaharian utama. Akan tetapi, produk perikanan landak laut termasuk olahannya seperti kukure (Fig. 2) telah lama memasyarakat dan menjadi sumber pangan dan sumber protein masyarakat setempat. Olahan kukure tersebut bahkan juga telah dikonsumsi oleh masyarakat di P. Tomia, Kepulauan Wakatobi (Nane 2019a; Nane 2019c; Nane, 2019d).

Cara pembuatan olahan kukure hampir sama bahkan sama. Diawali dengan memisahkan telur dari cangkangnya menggunakan tangan atau sendok. Kemudian telurnya dimasukkan kembali ke dalam cangkang landak laut $D$. setosum yang duridurinya sudah digundulkan dan dibersihkan isinya (lambung dan ususnya) untuk dijadikan sebagai kemasan. Adapun proses pemasakan olahan kukure ini dilakukan dengan cara dikukus.

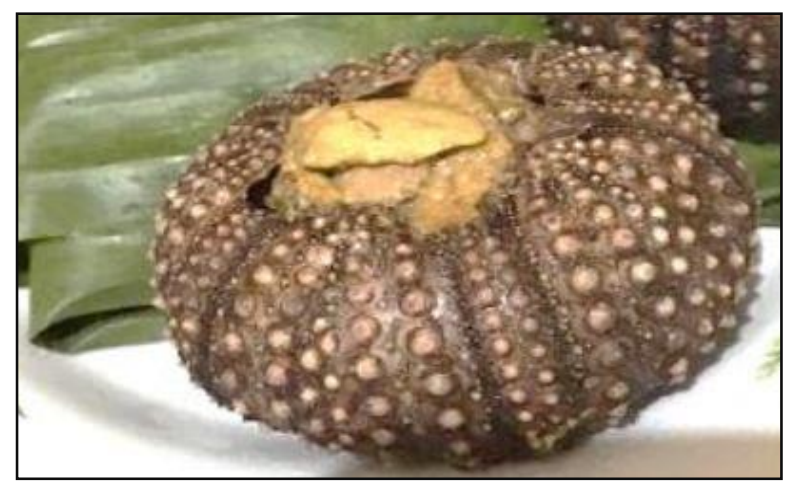

Fig. 2. Produk kukure Diademe setosum

Kegiatan penangkapan landak laut $D$. setosum di $\mathrm{P}$. Taliabu masih bersifat rekreasi dan juga tradisional. Bahkan pola tangkap rekreasi ini telah menjadi budaya atau kearifan lokal setempat yang terjaga secara turun temurun dan menjadi bagian dari kebudayaan masyarakat setempat. Karena itu, perikanan 
landak laut D. setosum masih terjaga sekarang karena mudah dalam kelestariannya dan stoknya juga masih pengoperasiannya. Selain itu, bila dioperasikan melimpah. Sungguh pun kegiatan penangkapan telah lama dilakukan.

Keberlanjutan itu, terjadi karena selain karena pola tangkap yang masih tradisional, Hal lain yang juga mendukung keberlanjutan perikanan landak laut D. setosum di $P$. Taliabu adalah sarana dan/atau tangkap yang digunakan oleh nelayan yang masih sederhana dan klasik. Alat tangkap yang umumnya digunakan hanyalah berupa sebilah parang tumpul dan karinda. Karinda merupakan kerajang yang berlubang-lubang menyerupai mata bubu yang dianyam dari bilahan rotan dan/atau bambu.

Parang digunakan untuk memotong duriduri beracun pada landak laut $D$. setosum. Selain itu, digunakan juga untuk solo atau menyolo telur landak laut. Solo merupakan bahasa lokal yang artinya mengecek atau memeriksa. Biasanya untuk mengecek kematangan atau ukuran telur landak laut apakah sudah matang atau tidak dan apakah sudah berukuran besar/panen ataukah belum. Teknik ini dikenal dengan nama solo. Nelayan percaya bahwa bila landak laut $D$. setosum yang hidup secara berkelompok, salah satunya telah matang-gonad, maka semua individu dalam kelompok itu pun telah masak dan layak untuk dipanen.

Sementara itu, karinda digunakan sebagai wadah untuk memasukkan landak laut $D$. setosum. Penggunaan karinda dianggap lebih efektif dan masih dipertahankan sampai dalam air. Ketika diangkat air akan langsung tertiris keluar.

Meskipun pola pemanfaatan telur landak laut D. setosum masih dalam skala kecil, tradisional dan bersifat rekreasi saja. Namun, minat masyarakat tempatan pada produk telur landak laut sangat tinggi. Hal ini dapat dibuktikan dengan kemampuan bersaing komoditas perikanan landak laut di pasar-pasar lokal dengan produk perikanan lainnya seperti ikan kakap, tuna, kerapu dan sebagainya.

Artinya, meskipun produk perikanan lain melimpah. Namun minat masyarakat terhadap telur landak laut $D$. setosum tidak menurun melainkan tetap menjadi primadona masyarakat setempat. Hal ini dikarenakan, produk perikanan landak laut terutama telur landak laut ini punya keunikan cita rasanya.

Selain itu, masyarakat setempat tidak selamanya dapat mengonsumsi telur landak laut. Karena produk telur landak laut sifatnya musiman. Sehingga tidak tersedia setiap hari di pasar. Produk landak laut ada di pasar bila pada saat musim saja. Karena itu, perikanan landak laut dianggap berkah bila musim tiba karena meningkatkan pendapatan nelayan setempat.

Secara alami, tingkat kematangan telur landak laut $D$. setosum ini cukup unik karena kematangan telur landak laut antara wilayah yang satu dengan yang lain bisa berbeda. Perbedaan masa atau periode kematangan ini umumnya dipengaruhi oleh faktor lingkungan 
yang memang memengaruhi pola perkembangan dan kematangan telur. Dan juga usia landak laut. Untuk landak laut yang hidup pada perairan yang relatif hangat dan masih dapat ditoleransi oleh landak laut umumnya mengalami perkembangan dan kematangan yang relatif lebih cepat dibanding dengan landak laut yang hidup pada daerah dengan temperatur yang rendah.

Dari hasil survei, kami menemukan bahwa landak laut $D$. setosum yang hidup pada daerah dangkal memiliki tingkat kematangan gonad yang cepat dibanding dengan landak laut yang hidup pada perairan dalam. Selain itu, ketersediaan pakan juga memengaruhi perkembangan dan kualitas telur landak laut.

Penangkapan landak laut $D$. setosum di $P$. Taliabu telah berlangsung sejak lama. Namun daerah penangkapan masyarakat nelayan belum berpindah. Artinya lokasi penangkapan masih cukup menyediakan stok bagi nelayan penangkap landak laut di daerah tangkapan.

Hal lain yang juga mendukung keberlanjutan perikanan Landak Laut $D$. setosum di P. Taliabu adalah cara penangkapannya. Di sana Penangkapan landak laut lebih banyak dilakukan pada saat air surut. Sangat jarang dilakukan penangkapan pada saat air pasang. Bahkan, pada musim tertentu pada saat surut tidak dilakukan penangkapan. Bila setelah dicek atau di-solo ternyata telur landak laut belum berisi. Artinya stok tersebut belum layak dipanen. Masyarakat pesisir di P. Taliabu secara sadar tidak melakukan penangkapan landak laut $D$. setosum sama sekali dan membiarkannya di alam sampai membesar. Setelah itu bila sudah berisi barulah dipanen Kembali.

Kondisi di atas bila dihubungkan dengan pertanyaan apakah pemanfaatan atau penangkapan landak laut $D$. setosum di $P$. Taliabu sudah mengalami overfishing. Maka jawabannya belum. Karena belum ada sama sekali ciri-ciri atau gejala overfishing; seperti semakin jauhnya lokasi penangkapan; semakin kecilnya ukuran landak laut $D$. setosum ataujumlahnya yang semakin sedikit di alam akibat kegiatan penangkapan.

Hal ini, sangat berbeda dengan hasil penelitian kami sebelumnya di P. Tomia Wakatobi tentang pemanfaatan perikanan landak laut Tripneustes gratilla yang telah mengalami overfishing sehingga mengakibatkan jumlah landak laut di alam semakin berkurang dan lokasi penangkapan semakin jauh (Nane, 2019b; Nane \& Paramata, 2020).

\section{Conclusion}

Berdasarkan uraian dan penjelasan di atas, maka dapat disimpulkan bahwa pemanfaatan landak laut di P. Taliabu, Maluku utara masih dilakukan secara tradisional. Namun pemanfaatannya masih berkelanjutan (belum overfishing). Karena belum ditemukan ciri-ciri gejala overfishing pada sumber daya yang diamati. Selain itu, olahan pemanfaatan landak laut yang ada di P. Taliabu berupa olahan produk kukure yang dikemas dalam cangkang asli. 


\section{References}

Nane, L. (2019a). Efisiensi Mesin Teknologi Sapurata Dalam Mengoptimalisasi Produksi Inovasi Pangan Kukure Di Pulau Barrang Lompo, Makassar. https://doi.org/10.31230/osf.io/q8spg

Nane, L. (2019b). Impact of overfishing on density and test-diameter size of the sea urchin Tripneustes gratilla at Wakatobi Archipelago, south-eastern Sulawesi, Indonesia. BioRxiv, 727271. https://www.biorxiv.org/content/10.1101/727271v1

Nane, L. (2019c). Sea Urchin Sustainability Studies Based on Dimension Biology, Ecology and Technology at Around of Tolandono Island and Sawa Island at Wakatobi Conservation Area. https://doi.org/10.31230/osf.io/4whz6

Nane, L. (2019d). Studi Keberlanjutan Perikanan Landak Laut Berdasarkan Dimensi Biologi, Ekologi Dan Teknologi Di Sekitar Pulau Tolandono Dan Pulausawa Kawasan Konservasiwakatobi [Skripsi, Universitas Hasanuddin]. https://Marxiv.Org/9zdvr/

Nane, L., \& Paramata, A. R. (2020). Impact of Overfishing on Density and Test-Diameter Size of the Sea Urchin Tripneustes gratilla at Wakatobi Archipelago, South-Eastern Sulawesi, Indonesia. ILMU KELAUTAN: Indonesian Journal of Marine Sciences, 25(2), 53-56. https://doi.org/10.14710/ik.ijms.25.2.53-56

Nane, L., Baruadi, A. S. R., \& Mardin, H. (2020). The density of the blue-black urchin Echinotrix diadema (Linnaeus, 1758) in TominiBay, Indonesia. Tomini Journal of Aquatic Science, 1(1), 16-21. https://doi.org/10.37905/tjas.v1i1.5939 